\title{
Effects of sewage-derived nutrients on an estuarine macrobenthic community
}

\author{
Candida Savage*, Ragnar Elmgren, Ulf Larsson \\ Department of Systems Ecology, Stockholm University, 10691 Stockholm, Sweden
}

\begin{abstract}
Eutrophication is one of the foremost threats to coastal ecosystems today. Enhanced sewage treatment has often been implemented as a means of counteracting eutrophication by reducing point source inputs of nutrients to estuaries. A $23 \mathrm{yr}$ record (1972 to 1994) of macrobenthic communities in Himmerfjärden bay, Sweden, a coastal embayment of the Baltic proper, was evaluated in relation to nutrient discharges and physicochemical parameters. The study period started before the onset of sewage discharge and covers the introduction of improved $(50 \%)$ nitrogen $(\mathrm{N})$ removal from the local sewage treatment plant, which by 1994 served 240000 people. Analysis of temporal variability in species abundance and biomass showed that macrobenthos conformed to general models of organic enrichment. Common species (Macoma balthica, Monoporeia affinis) increased during initial, moderate nutrient loading, but both density and biomass were reduced when nutrient inputs increased further, especially in the deeper basins (>35 m). Redundancy analysis (RDA) of both whole bay and basin-specific community changes identified sewage-derived $\mathrm{N}$ as the variable that best explained macrobenthic variability. The abundance of most taxa was negatively correlated to annual loads of sewage $\mathrm{N}$. Comparison among inner, middle and outer reaches of the bay showed that the impacts of sewage $\mathrm{N}$ on species abundance declined with distance from the outfall. Overall, RDA using abundance data was more sensitive than biomass-based analyses and suggested that full community recovery was not complete $5 \mathrm{yr}$ after introduction of a $\mathrm{N}$ removal step in the sewage treatment. Finally, although sewage-derived nutrient impacts were evident even $20 \mathrm{~km}$ distant from the point source, comparisons among local basins showed that local physical features (e.g. sill depth) can greatly ameliorate or enhance impacts and highlighted the need for spatially explicit studies to detect human impacts.
\end{abstract}

KEY WORDS: Coastal eutrophication - Nutrient discharge $\cdot$ Treated sewage $\cdot$ Macrobenthos · Hypoxia $\cdot$ Multivariate $\cdot$ Nitrogen $\cdot$ Phosphorus

Resale or republication not permitted without written consent of the publisher

\section{INTRODUCTION}

Eutrophication of coastal water bodies is one of the greatest problems facing aquatic ecosystems today. Coastal eutrophication is fuelled by increases in landderived nitrogen $(\mathrm{N})$ and phosphorus $(\mathrm{P})$ inputs (Carpenter et al. 1998) that can be directly linked to increased urbanisation in coastal drainage basins or expanded agricultural activities (Howarth 1998). Estuaries are under heavy pressure as they link land with

*Email: candida@system.ecology.su.se the open sea and often receive human and industrial discharges. In particular, the limited water exchange and vertical stratification common in estuaries can worsen eutrophication and lead to oxygen-depleted bottom waters, increased areas of reduced sediments (Diaz \& Rosenberg 2001) and intensified impacts on biota living near the sediment-water interface (González-Oreja \& Saiz-Salinas 1998).

Macrobenthic assemblages integrate environmental disturbance and have frequently been used to describe human impacts along environmental gradients (e.g. Pearson \& Rosenberg 1978, Gray et al. 1990, Weston 1990, Warwick \& Clarke 1991, Rees et al. 1992, War- 
wick 1993, Cao et al. 1996). Macrobenthic communities often respond to elevated nutrient concentrations and increased organic matter production by an increase in biomass (Pearson \& Rosenberg 1978, Rosenberg 1985, Niermann et al. 1990, Weston 1990, Beukema 1991, Rees et al. 1992) indicating previous general food limitation. However, under excessive nutrient loads, the sedimentation of organic matter may exceed the rate of its degradation, and bottomwater oxygen can be exhausted and alter macrofaunal communities (Diaz \& Rosenberg 1995, 2001). Unfortunately, less is known about the factors regulating the recovery of benthos following pollution abatement (e.g. Wilson et al. 1998), principally because of a lack of contemporaneous data needed to identify factors that cause community change. A paucity of long, concomitant macrobenthic and environmental time series has often made it difficult to distinguish impacts of anthropogenic disturbance and natural fluctuations (Rees \& Eleftheriou 1989, Ferraro et al. 1991, Rakocinski et al. 1997). As a result, few studies have demonstrated how variations in nutrient fluxes alter macrobenthic communities in coastal areas over the long term, relative to the effects of other environmental factors.

The Baltic Sea is an excellent model system where anthropogenic eutrophication has affected benthic communities. An estimated 4-fold increase in $\mathrm{N}$ and an 8-fold increase in $\mathrm{P}$ inputs during the last century (Larsson et al. 1985) has elevated primary production by 30 to $70 \%$ and increased sedimentation by 70 to $190 \%$ (Elmgren 1989). This has resulted in a 5- to 7 -fold increase in macrofaunal biomass and abundance in much of the open Baltic proper between the 1920s and 1970s (Cederwall \& Elmgren 1980). However, in the last half century, bottom-water hypoxic events have increased in severity and frequency (Elmgren 1989, Bonsdorff et al. 1997a,b) leading to a reduction in the areal extent of macrobenthos (Andersin et al. 1978, Laine et al. 1997), particularly in the coastal zone of the Baltic proper (Cederwall \& Elmgren 1990, Powilleit \& Kube 1999). Unfortunately, even though large-scale nutrient abatement programmes started already in the 1970 s, there are few long-term studies of the recovery of disturbed macrobenthic communities after reduction of nutrient inputs.

Changes in macrozoobenthos in the coastal bay, Himmerfjärden, Sweden, have been monitored over a 23 yr period (1972 to 1994) encompassing the onset and gradual increase of the discharge from a sewage treatment plant (STP). Tertiary sewage treatment has removed $>90 \%$ of P since the start of the STP in 1974, and since 1988, has gradually improved with respect to $\mathrm{N}$ reduction, reaching $\sim 50 \% \mathrm{~N}$ removal by 1992 . Physicochemical and plankton data have been collected 20 to 25 times per year since 1976. The physical conditions of
Himmerfjärden bay make it a suitable area to explore the importance of sewage-derived nutrients on macrobenthos, as the estuary lacks tidal forcing and experiences only minor salinity fluctuations ( 2\%o seasonally and annually). In most estuaries, dynamic gradients of salinity and other factors can stress benthic communities and complicate the assessment of anthropogenic disturbance (Ferraro et al. 1991, Engle et al. 1994, Rakocinski et al. 1997). The sediment is fairly homogeneous over much of the soft-bottom areas of Himmerfjärden and is characterised by an organic-rich upper layer underlain by argillaceous mud (Blomqvist et al. 1992). Moreover, sediment granulometry is generally not an important structuring factor for Baltic Sea macrobenthos in fine sediments (Ankar \& Elmgren 1976). This reduces the confounding effects of different sediment characteristics on benthos structure (Wilson et al. 1998, Lindegarth \& Hoskin 2001) and facilitates identification of nutrient discharge impacts.

Using multivariate analyses, we tested the hypotheses that (1) macrofaunal communities would be negatively impacted by an increased nutrient loading; (2) macrofaunal communities would partially recover following improvements in sewage treatment; and (3) the influence of the sewage treatment plant would be most pronounced near the outfall in the inner basin of the bay. Although multivariate analyses cannot prove causality, the correlations identify likely speciesenvironmental relationships and help refine hypotheses for further evaluation.

\section{MATERIALS AND METHODS}

Description of the study area and nutrient loading history. Himmerfjärden is a coastal bay of the Baltic Sea proper in the archipelago south of Stockholm, Sweden, which receives treated sewage near its northern head (Fig. 1). There are 4 natural basins within Himmerfjärden that delineate the inner, central and outer reaches, and the northern arm of the bay that is connected to Lake Mälaren through a sluice at the town of Södertälje (Engqvist 1996). The drainage basin of $1286 \mathrm{~km}^{2}$ is mainly forest and agricultural land. The bay has an area of $174 \mathrm{~km}^{2}$, a mean depth of $17 \mathrm{~m}$ with deeper regions of $50 \mathrm{~m}$ and an average salinity of $6 \%$, and lacks tidal forcing. Himmerfjärden is usually stratified during summer and can experience hypoxic bottom-waters and reduced surficial sediments, especially in the deeper and more stagnant areas of the bay. In autumn, stratification breaks down and the water column becomes well mixed. Water exchange with the open Baltic may also be limited during severe winters, when ice cover prevents wind-induced mixing (Elmgren \& Larsson 1997). 
Fig. 1. Location of the sewage treatment plant (STP), the 14 macrobenthic sampling stations (6 to 21 ), the 4 environmental monitoring stations ( $\mathrm{H} 2$ to H5) and the coastal reference station (B1) at Himmerfjärden bay

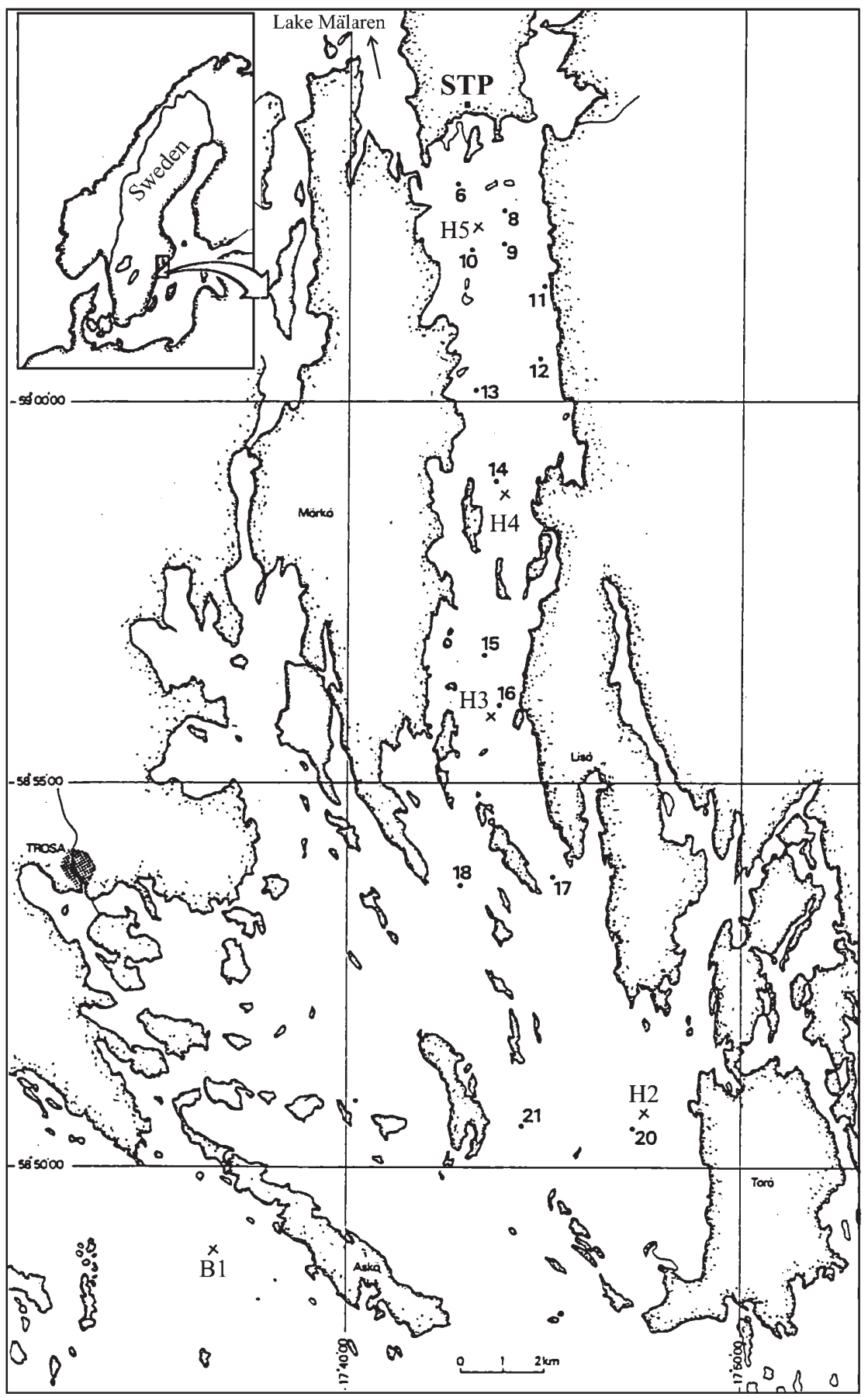

Primary production in Himmerfjärden was generally N-limited during the study period except for the inner basins, where $\mathrm{P}$ limitation during spring and early summer was normal (Elmgren \& Larsson 2001). Overall, treated sewage was the main $\mathrm{N}$ source from land to the bay, while $\mathrm{P}$ was derived predominantly from freshwater input (Elmgren \& Larsson 1997). Prior to 1974, a small amount of primary treated sewage was discharged into the inner basin of Himmerfjärden bay, near the Lake Mälaren outlet. The Himmerfjärdsverket STP started operating in 1974, originally serving 90000 people and discharging treated wastewater primarily in the form of dissolved inorganic nitrogen (DIN). As the number of people served increased, sewage-derived $\mathrm{N}$ gradually increased from $\sim 300$ t $\mathrm{N}$ released during 1974 to over 700 t N in 1982 (Fig. 2a). Between 1985 and 1989, the number of people served reached 240000 and annual $\mathrm{N}$ discharge increased to 

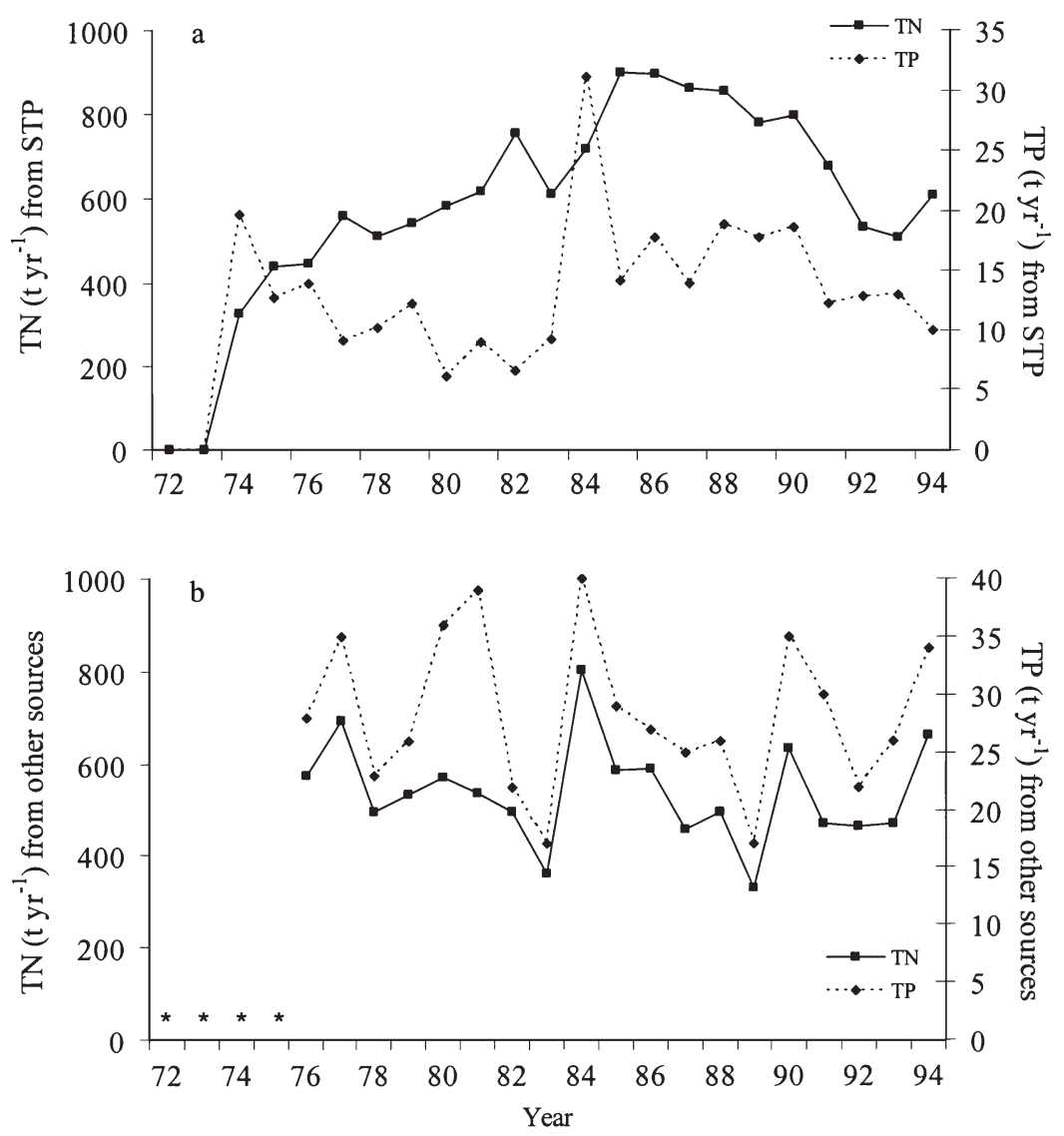

Fig. 2. Annual total nitrogen (TN) and total phosphorus (TP) discharge

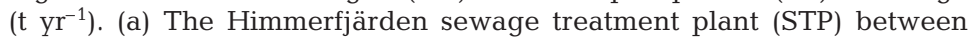
1972 and 1994. (b) Other sources, estimated from measured stream and Lake Mälaren nutrient concentrations and flow rates, and atmospheric deposition between 1976 and 1994. *No nutrient concentrations available

formaldehyde solution containing Rose Bengal stain. Macrobenthic organisms were later sorted and identified to species or higher taxon. Biomass was measured as wet weight with shells, after blotting dry. Rare taxa (all rare taxa in aggregate were $<2 \%$ total biomass and $<1 \%$ total abundance) were not identified before 1989 and were therefore excluded from analyses. Multivariate analyses of macrobenthic community change were performed on the 5 most common species: Macoma balthica (Bivalvia), Monoporeia affinis (Amphipoda), Pontoporeia femorata (Amphipoda), Halicryptus spinulosus (Priapulida) and Harmothoe sarsi (Polychaeta), which represented $>90 \%$ of the total community biomass and abundance.

From 1976, environmental parameters were measured at 4 monitoring stations (H2 to H5) and a coastal reference station (B1) (Fig. 1), including water column nutrient profiles, water temperature and dissolved oxygen concentration. Measurements were made weekly during spring, bi-weekly during summer and autumn, and at monthly intervals in the winter (Table 1). Weather data, including daily precipitation, from the Landsort weather observatory $\left(58^{\circ} 36^{\prime} \mathrm{N}\right.$, $\left.16^{\circ} 58^{\prime} \mathrm{E}\right)$ near the bay's outlet were obtained from the Swedish Meteorological and Hydrological Institute (SMHI).

Numerical analyses. Multivariate analyses of macrobenthic abundance (ind. $\times 0.1 \mathrm{~m}^{-2}$ ) and biomass $\left(\mathrm{g} \times 0.1 \mathrm{~m}^{-2}\right)$ were used to

a maximum of $\sim 900 \mathrm{t} \mathrm{N}$. Thereafter, increasingly efficient $\mathrm{N}$ removal procedures were implemented, so that by 1992, the plant discharged $\sim 500$ t $\mathrm{N}$ annually. Sewage-derived $\mathrm{P}$ influx varied from 6 to $20 \mathrm{t} \mathrm{P} \mathrm{yr}^{-1}$, with no clear relation to the population served. In 1983 to $1984,31 \mathrm{t}$ P was deliberately released from the STP to evaluate whether primary production in the bay was mainly P- or N-limited.

Sampling. Macrobenthic community sampling was conducted at 14 stations along a gradient from the sewage treatment plant to the outer parts of the bay (Fig. 1). A total of 1391 grab samples were taken between 1972 and 1994. Sampling was conducted in October every year, by which time the major recruitment for the year had occurred. On each sampling occasion, an average of 3 replicate $0.1 \mathrm{~m}^{2}$ van Veen grab samples (Ankar 1977) were taken at each station, with some stations having up to 10 replicate grabs in several years. Samples were sieved through a $1 \mathrm{~mm}$ sieve and sieve residues preserved in buffered $4 \%$ quantify changes in zoobenthic community composition within Himmerfjärden. Analyses were performed on the entire bay, as well as separately on selected stations from different sub-basins, to evaluate how sewage impacts on benthos varied as a function of distance from the outfall.

Whole bay analysis: Macrobenthic community data were pooled and standardised from all 14 stations to measure long-term temporal changes in the community composition and biomass throughout the bay. To simplify data structure and focus on temporal trends in the community, replicate grab samples from each station were averaged. Cluster analysis and non-metric multidimensional scaling (MDS) were used to describe temporal changes in the macrobenthic community (Field et al. 1982) and to discern whether recovery towards pre-discharge conditions followed when the $\mathrm{N}$ discharge was reduced. The MDS arranges the data in 2-dimensional space, such that points which are positioned close together in the ordination plot correspond 
to years that are similar in terms of species composition or biomass. Hierarchical agglomerative clustering and MDS were performed using PRIMER (Plymouth Routines In Marine Ecological Research) version 4.0 software (Clarke 1993). Species data from 1972 to 1994 were 4 th-root transformed to downweight abundant taxa (Macoma balthica) and community trends were described using the Bray-Curtis coefficient of similarity. Only 2 stations were sampled in 1974, and only 6 stations in 1978; these 2 yr are therefore excluded from the whole bay MDS analyses as the sampled stations were not evenly distributed throughout the bay. Species responsible for the observed groupings were identified by using the similarity percentages (SIMPER) routine in PRIMER.

To explore the relationships between physicochemical conditions, nutrient loading and macrobenthic community structure in Himmerfjärden, historical changes in faunal abundance and biomass were summarised as a function of the measured environmental parameters using CANOCO version 4.0 (Ter Braak 1990). Based on the outcome of preliminary detrended correspondence analyses (DCA), species-environmental correlations were described using linear models. Principal components analysis (PCA) and redundancy analysis (RDA) were performed using $\log (x+1)$-transformed species abundance and biomass data. Ordination axes were centred by species. An exploratory PCA was performed to assess how much community variance could be explained in a 2-dimensional ordination. RDA was then employed to test the strength of relationships between macrofaunal community change and measured environmental variables. RDA is a constrained ordination that selects the linear combination of environmental variables that maximises the dispersion of the species scores and thereby ascertains which environmental variables are best correlated to community changes (Jongman et al. 1995).

RDA was run initially using macrobenthic community data and 11 environmental parameters from 1976 to 1994 , to identify which factors were correlated to changes in community composition and biomass. Nutrient, physicochemical and climatic parameters included in the initial RDA model are listed in Table 1. Nutrient variables included total annual inputs of $\mathrm{N}$ and P from the sewage treatment plant, other sources of $\mathrm{N}$ and $\mathrm{P}$ entering the bay (Fig. 2b) estimated from water flow and nutrient concentrations measured in the streams entering Himmerfjärden, including outflow from Lake Mälaren and atmospheric deposition of

Table 1. Nutrient, physicochemical and climatic parameters, sampling frequencies (1976 to 1994) and the units included in the initial RDA model for the Himmerfjärden whole bay and basin-wide analyses

\begin{tabular}{|c|c|c|}
\hline Environmental parameter & Sampling frequency & Unit used in analyses \\
\hline \multicolumn{3}{|l|}{ Nutrients } \\
\hline Sewage N discharge (N_stp) & Daily & Annual total $\left({\left.\mathrm{t} \mathrm{yr}^{-1}\right)}^{-1}\right.$ \\
\hline Sewage P discharge (P_stp) & Daily & Annual total $\left({\left.\mathrm{t} \mathrm{yr}^{-1}\right)}^{-1}\right.$ \\
\hline Estimated $\mathrm{N}$ from other sources $\left(\mathrm{N}_{\text {_other }}\right)$ & Monthly & Annual total $\left({\left.\mathrm{t} \mathrm{yr}^{-1}\right)}\right.$ \\
\hline Estimated $\mathrm{P}$ from other sources $\left(\mathrm{P}_{-o t h e r}\right)$ & Monthly & Annual total $\left({\left.\mathrm{t} \mathrm{yr}^{-1}\right)}^{-1}\right.$ \\
\hline TN in coastal reference station (TN_B1) & $\begin{array}{l}\text { Weekly (Mar to Apr) } \\
\text { Bi-weekly (May to Oct) } \\
\text { Monthly (Nov to Feb) }\end{array}$ & Mean annual average 20 to $35 \mathrm{~m}\left({\left.\mu \mathrm{g} \mathrm{l}^{-1}\right)}\right.$ \\
\hline TP in coastal reference station (TP_B1) & $\begin{array}{l}\text { Weekly (Mar to Apr) } \\
\text { Bi-weekly (May to Oct) } \\
\text { Monthly (Nov to Feb) }\end{array}$ & Mean annual average 20 to $35 \mathrm{~m}\left({\left.\mu \mathrm{g} \mathrm{l}^{-1}\right)}\right.$ \\
\hline \multicolumn{3}{|l|}{ Physico-chemical parameters } \\
\hline Dissolved oxygen concentration & $\begin{array}{l}\text { Weekly (Mar to Apr) } \\
\text { Bi-weekly (May to Oct) } \\
\text { Monthly (Nov to Feb) }\end{array}$ & Annual mean minima $\left(\mathrm{mg} \mathrm{O}_{2} \mathrm{l}^{-1}\right)$ \\
\hline Hypoxic period & & Days $<4 \mathrm{mg} \mathrm{O}_{2} \mathrm{l}^{-1}(\mathrm{~d})$ \\
\hline Chlorophyll a concentration & $\begin{array}{l}\text { Weekly (Mar to Apr) } \\
\text { Bi-weekly (May to Oct) } \\
\text { Monthly (Nov to Feb) }\end{array}$ & Spring mean maxima 0 to $10 \mathrm{~m}$ integrated $\left(\mathrm{mg} \mathrm{m}^{-3}\right)$ \\
\hline \multicolumn{3}{|l|}{ Climatic parameters } \\
\hline Precipitation (measured at Landsort) & Daily & Annual total (mm) \\
\hline Winter NAO index & Daily (Dec to Feb) & Index \\
\hline
\end{tabular}


nutrients (Elmgren \& Larsson 1997). As a proxy for the influence of nutrients brought into the bay from the adjacent coastal zone through water exchange, mean annual total nitrogen (TN) and total phosphorus (TP) concentrations measured at the coastal reference station (B1) were also included. These concentrations are based on depth-integrated samples of water between 20 and $35 \mathrm{~m}$, since inflow to Himmerfjärden bay is normally from below-thermocline layers. Physicochemical variables measured at the central $\mathrm{H} 4$ monitoring station have the longest continuous sampling history and were therefore used in the whole bay analyses. The variables included in the RDA are dissolved oxygen concentration near the bottom and mean spring (March to April) chlorophyll a (chl a) concentration measured as the integrated 0 to $10 \mathrm{~m}$ chl a concentration. The period of hypoxia was estimated as the number of days when oxygen concentration in near-bottom water was $<4 \mathrm{mg} \mathrm{O}_{2} \mathrm{l}^{-1}$. Climatic variables included annual total precipitation as an estimate of diffuse runoff or wind-induced mixing, as high rainfall years are often associated with wind-induced water column mixing and hence, better deep water oxygen conditions. The winter North Atlantic Oscillation (NAO) index (December to March) was also included as a proxy for winter severity and hence, ice cover, with high NAO indices representing mild winters and low ice cover in northern Europe (Hurrell 1995).

Forward selection with Monte Carlo permutation tests (1000 permutations) was used to identify the minimal subset of environmental variables needed to explain the observed patterns of community change. The permutation test is a special case of randomisation tests that randomly reassigns environmental variables to species composition and tests for significance. Environmental variables were retained in the subsequent restricted RDA analysis if they independently explained a significant $(p<0.05)$ amount of variance in the species data. Using these criteria, the significant variables were identified and a redundancy analysis performed using the statistical options outlined above.

Basin-specific analysis: To examine the factors underlying macrobenthic community change in individual sub-basins, ordinations were performed independently using time series from the inner, central and outer regions. We expected the treatment plant to have most pronounced effects on the benthos in the inner reaches, nearest the sewage outfall. Preliminary cluster analysis using all 14 sampling stations identified 3 main groups of stations that coincided with the inner, central and outer reaches of the bay (data not shown). From these groupings, we chose the stations with the longest contiguous time series that were also representative of other stations in that region based on the results of cluster analysis. Final site selection included
Stn 6 from the inner reaches, Stn 16 for the central region and Stn 20 for the outer region (Fig. 1). The biota from these stations were compared to the environmental data collected at the monitoring Stns H5, H4 and H2, respectively, using data from 1976 to 1994. Missing environmental data at Stns H2 and H5 were approximated by taking the average value for that station for the 2 preceding and 2 following years. The same procedure used for the whole bay analyses was applied to the basin-level analyses. Exploratory PCA was used to assess community variance. Constrained ordination (RDA) was then performed using all 11 environmental variables (Table 1), but using the physicochemical parameters measured at the respective monitoring stations. Monte Carlo permutation tests were used to identify the significant $(p<0.05)$ environmental variables and a second RDA performed using the refined data sets.

\section{RESULTS}

\section{Temporal change in macrobenthos}

The macrobenthic community exhibited pronounced inter-annual changes in abundance (Fig. 3) and biomass at the individual sampling stations. Macrobenthic biomass was dominated ( $>90 \%$ ) by the tellinid clam Macoma balthica. The biomass data at the individual stations therefore largely mirror the changes in abundance of $M$. balthica and are not shown here, but are discussed when relevant. Macrobenthic density and biomass at the inner stations $(6,8,9$ and 10) were elevated in the early 1970s and again between 1990 and 1994. A near total die-off occurred at the inner stations in 1980, and they remained depauperate until 1989, when numbers increased incrementally, particularly populations of $M$. balthica. The average population of M. balthica fluctuated between 600 and 2200 ind. $\mathrm{m}^{-2}$, except between 1980 and 1989, when abundance at the inner stations decreased to $<200$ ind. $\mathrm{m}^{-2}$. At the inner stations, biomass of $M$. balthica also peaked in 1973 to 1975 and in 1993 to 1994 , contributing between 150 and $450 \mathrm{~g} \mathrm{~m}^{-2}$ to community biomass. The amphipod Monoporeia affinis was an important component of the community in the inner stations before sewage impact (1972 to 1974), especially at Stn 8. In contrast to M. balthica, densities of Monoporeia affinis did not recover in the inner reaches of the bay after 1989. The other species were generally low throughout the study period, apart from Harmothoe sarsi which occurred occasionally at the inner stations, especially prior to 1980.

In the middle reaches of Himmerfjärden, the stations (11 to 17 ) exhibited high spatial and temporal vari- 


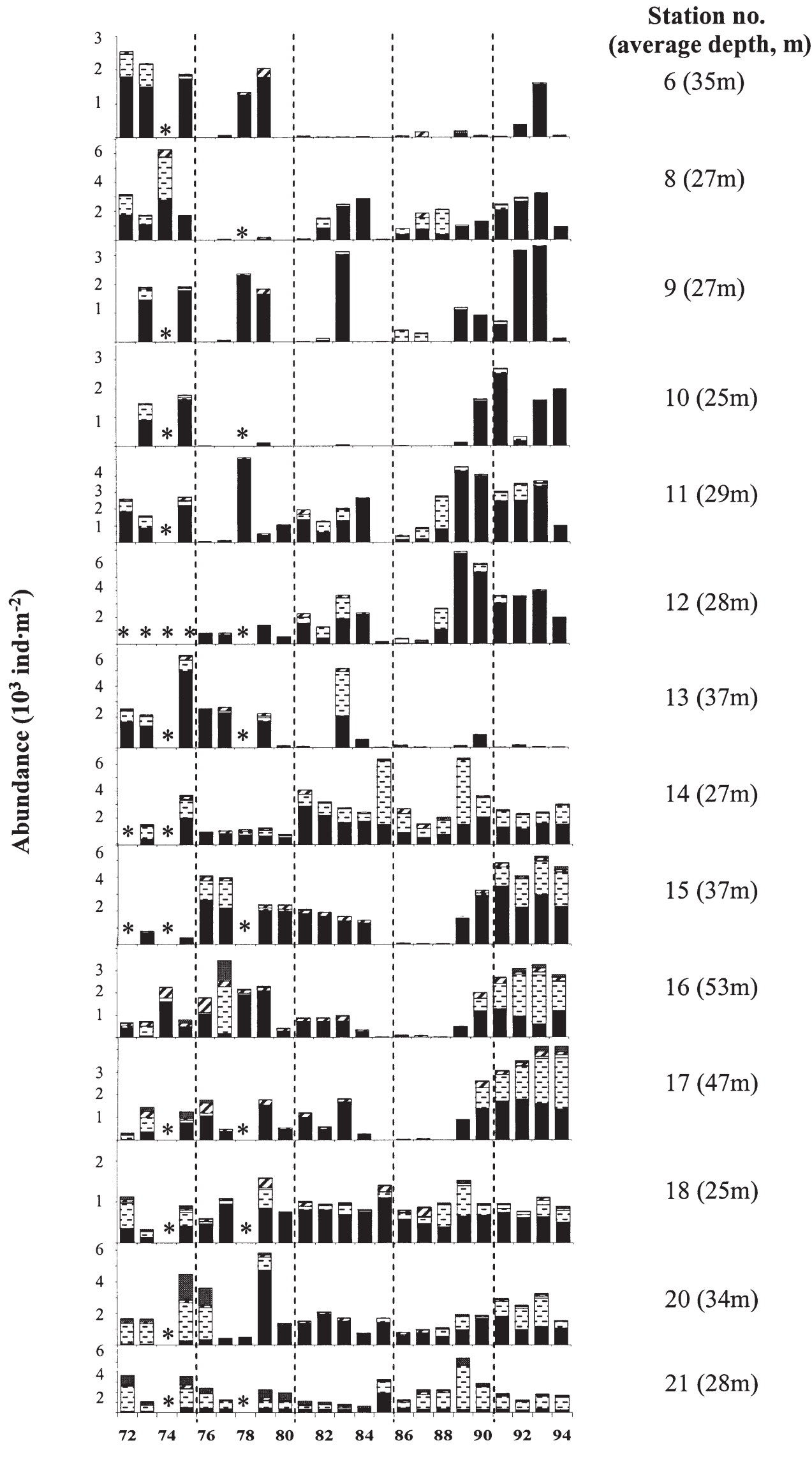

Station no.

$6(35 \mathrm{~m})$

$8(27 \mathrm{~m})$

$9(27 \mathrm{~m})$

$10(25 \mathrm{~m})$

$11(29 m)$

$12(28 \mathrm{~m})$

$13(37 \mathrm{~m})$

$14(27 \mathrm{~m})$

$15(37 \mathrm{~m})$

- P. fomorata

口H. sarsi

$\square H$ spinulosus

曰M. affinis

- M. balthica

Fig. 3. Temporal change in abundance $\left(10^{3}\right.$ ind. $\left.\mathrm{m}^{-2}\right)$ of the 5 most common macrobenthic species in Himmerfjärden bay between 1972 and 1994, averaged over all replicate grab samples from each sampling station. In most years, all 14 stations were sampled, except in 1972, 1974 and 1978 when $<10$ stations were sampled. *Not sampled. Station numbers are presented on the right with the average depth of the station (m) 
ability. Generally, macrobenthos declined to historical minima in 1985, except at Stn 14, which is shallower than most stations. Stn 14 never exhibited total benthic die-off during the study period, even in years of recorded hypoxia. Macoma balthica dominated the community biomass at Stn 14, but abundance was often dominated by Monoporeia affinis, which peaked in 1985 and 1989 with more than 4500 ind. $\mathrm{m}^{-2}$. The other stations in the middle reaches of the bay generally had high densities from 1988, except Stn 13, which showed no recovery following a hypoxic event in 1984. Macrobenthic biomass in the central reaches was dominated by $M$. balthica, but in terms of species abundance, M. affinis populations often exceeded 2000 ind. $\mathrm{m}^{-2}$ between 1990 and 1994 at Stns 15, 16 and 17. As for the inner stations, the other species were a minor component of the macrobenthic community, except at Stn 16, where between 500 and 1000 ind. $\mathrm{m}^{-2}$ of Harmothoe sarsi occurred in the mid-1970s and a population of Pontoporeia femorata ( 250 ind. $\mathrm{m}^{-2}$ ) was sampled in 1977. H. sarsi appeared again at Stns 16 and 17 from 1990 onwards.

No documented die-off occurred at the outer stations (18, 20 and 21), except for amphipods at Stn 21 following an oil spill in late 1977 (Elmgren et al. 1983). Generally, these stations had relatively high numbers of amphipods, Monoporeia affinis (between 500 and 2500 ind. $\mathrm{m}^{-2}$ ) and Pontoporeia femorata (between 200 and 2000 ind. $\mathrm{m}^{-2}$ ) between 1972 to 1976 . Biomass was low in the 1970s as densities of Macoma balthica were low $\left(<1000\right.$ ind $\left.\mathrm{m}^{-2}\right)$. Numbers of $M$. balthica increased from 1980 to 1985 , especially at Stns 18 and 20, contributing to an increase in biomass but not a notable increase in overall density. From 1986, amphipod populations increased with a peak in M. affinis populations in 1989 (>4000 ind. $\mathrm{m}^{-2}$ at Stn 21). Abundance of Halicryptus spinulosus was low throughout the bay during the study.

\section{Community similarity}

Averaged over the whole bay, cluster analysis at $90 \%$ Bray-Curtis similarity and non-metric MDS identified 4 distinct macrobenthic assemblages in terms of abundance (Fig. 4). Cluster analysis grouped communities collected before and just after the STP started discharging into the bay (1972 to 1975) and communities sampled in 1983 and 1989 to 1994. These samples were characterised by large populations of Macoma balthica and Monoporeia affinis. Macrofaunal assemblages between 1989 and 1994 represent the period of gradual introduction of improved $\mathrm{N}$ removal and were grouped together with the communities sampled in the early years of discharge, while 1983 was a year of unusually low $\mathrm{N}$ input from land sources other than the STP (Fig. 2b). However, within this cluster there is a distinction (at $93 \%$ Bray-Curtis similarity) between the 1970 s and the 1990s macrobenthic communities, largely due to the reduction in $M$. affinis populations in the 1990s compared to the predischarge communities. A second cluster groups macrobenthic communities from 1976 to 1982 except 1980, when annual $\mathrm{N}$ loads from the STP increased incrementally from 400 to $700 \mathrm{t}$. This group is characterised by relatively high numbers of $M$. balthica and $M$. affinis, although populations were not as high as in the early 1970s or 1990s. Macrobenthic samples collected during the period of maximum sewage $\mathrm{N}$ influx (1985 to 1988), when sewage-derived $\mathrm{N}$ exceeded $800 \mathrm{t} \mathrm{yr}^{-1}$, form a 3rd cluster composed of low numbers of $M$. balthica. A 4th cluster of samples from 1980 and 1984 represented years of extremely low density of $M$. affinis, following episodes of bottom-water hypoxia. Interannual changes in macrofaunal composition and density exhibit pronounced shifts in the years of recorded hypoxia (1976, 1980 and 1984). It is also of interest to

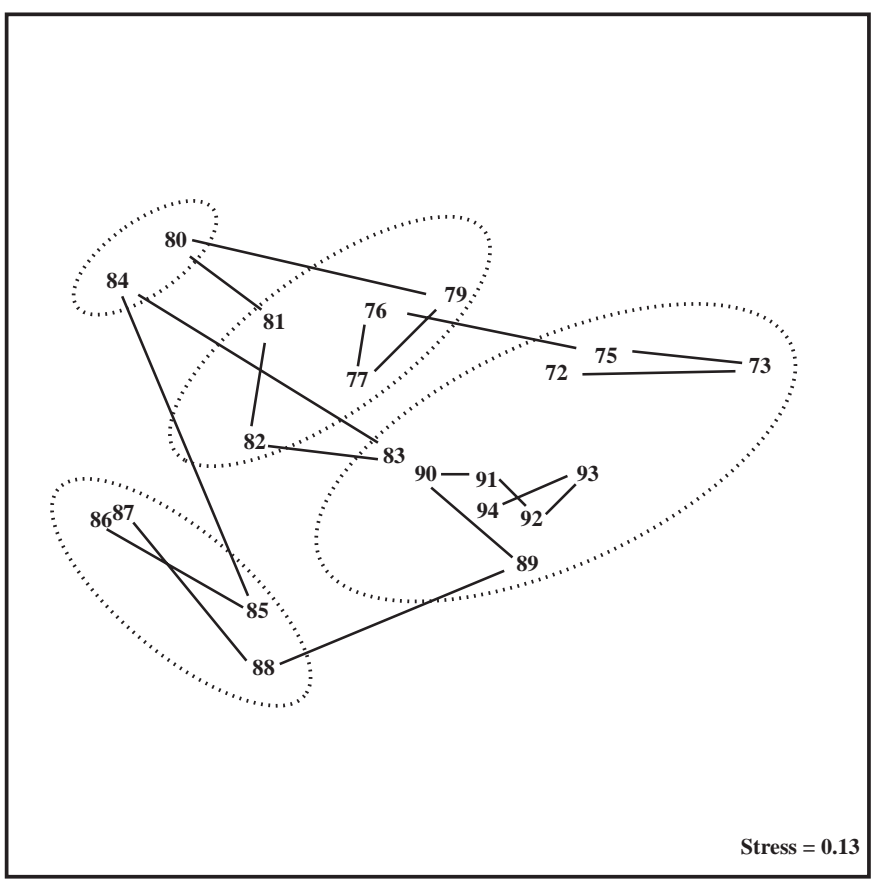

Fig. 4. Multidimensional scaling ordination showing the temporal variability in macrofaunal abundance of Himmerfjärden Bay with consecutive years joined to show the magnitude of inter-annual community change. Macrofaunal data are averaged over the sampled stations. Data from 1974 and 1978 are excluded as only 2 stations in 1974 and 6 stations in 1978 were sampled. Groupings indicated by the dotted lines reflect the results of cluster analysis at $90 \%$ Bray-Curtis similarity 
note that following enhanced sewage treatment (from 1989 onwards), the relative magnitude of inter-annual community change decreased, as shown by the decrease in the distance between consecutive years in the ordination plot.

Cluster analysis and MDS ordination of macrobenthic biomass data largely mirrored the groupings of the abundance data and is not presented graphically here. Cluster analysis identified 3 groups of samples that distinguished between samples with a high biomass of both Monoporeia affinis and Macoma balthica (1975, 1991 to 1994), a 2nd group with a very high biomass of the amphipod $M$. affinis (1988 to 1989), and the remaining years which were retained in a cluster characterised by relatively low biomass of $M$. affinis.

\section{Whole bay species-environment relationships}

\section{Abundance}

The whole-bay PCA (not shown) explained $78 \%$ of the variance in the species abundance data along the 1st 2 axes. The redundancy analysis (RDA) explained $60 \%$ of variance in species abundance along the 1 st $(37 \%)$ and 2 nd $(23 \%)$ axes (Fig. 5a). According to Fig. 5a, other sources of nutrients besides the STP were negatively related to years with high TN concentrations at the coastal reference station. High precipitation years correlated with low winter NAO. Similarly, bottom-water oxygen minima were related positively to $\mathrm{TN}$ concentration at the coastal reference station and $\mathrm{N}$ loading from the STP along the 2nd axis. Unexpectedly, episodes of hypoxia were negatively related to $\mathrm{N}$ loading.

Monte Carlo permutation tests with forward selection were used to identify which environmental variables explained significant $(\mathrm{p}<0.05)$ amounts of variance in macrobenthic abundance (Table 2). Sewagederived $\mathrm{N}$ was found to be the strongest single determinant of community composition at the whole bay level $(p=0.009)$ and annual precipitation $(p=0.028)$ was also identified as significant.

RDA with a restricted set of environmental predictors showed that community composition was organised along gradients of sewage $\mathrm{N}$ discharge (RDA Axis 1) and annual precipitation (Axis 2) (Fig. 5b). The RDA explained $28 \%$ variance along the 1 st 2 axes (19 and $9 \%$, respectively), $70 \%$ of which is related to measured environmental variables, principally sewagederived N. Overall, there was a negative relationship between increased $\mathrm{N}$-loading and abundance of all the macrobenthic species, except Monoporeia affinis, which appeared negatively correlated with years of high rainfall.

\section{Biomass}

Over $75 \%$ of the variance in the macrobenthic biomass data was explained by the 1st PCA axis, with an additional $17 \%$ explained by the 2 nd axis (not shown). RDA of macrobenthic biomass using all 11 environ-
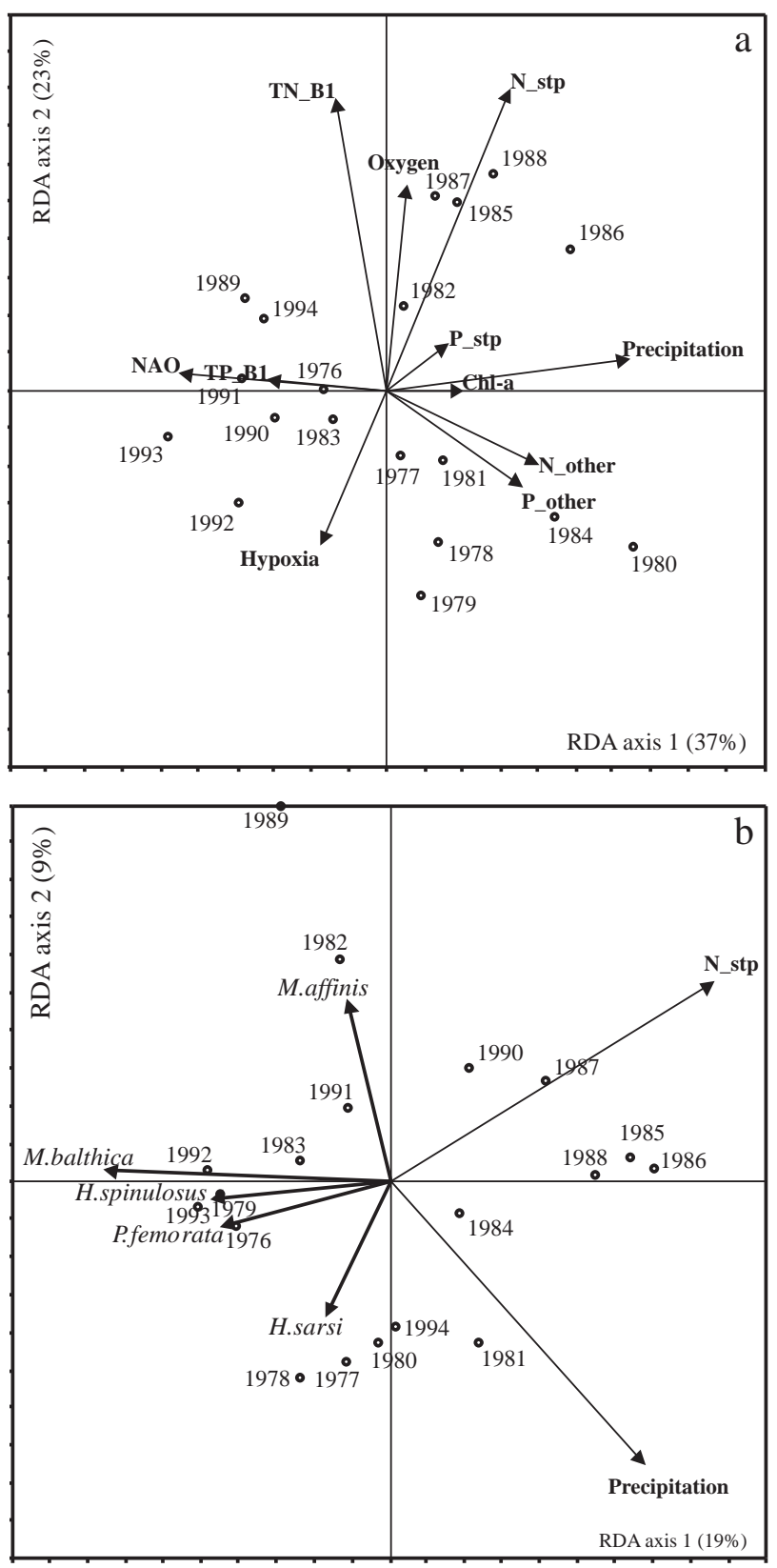

Fig. 5. Redundancy analyses (RDA) of Himmerfjärden's whole bay macrobenthic abundance data showing changes in macrobenthic community along (a) 11 environmental gradients (see Table 1) and (b) environmental variables identified as significant $(\mathrm{p}<0.05)$ by Monte Carlo permutation testing: $\mathrm{N}$ discharge from the sewage treatment plant (N_stp) and total annual precipitation (precipitation) 
mental variables was very similar to the abundance RDA (Fig. 5a) and is therefore not presented here. The first RDA axis explained $55 \%$ of the biomass data and was positively correlated to N-loading from the STP. Analogous to the abundance RDA, minimum oxygen concentration was positively related to increased sewage-derived N, while hypoxia was negatively correlated. TN concentration in the adjacent Baltic coastal zone separated out along the 2nd RDA axis, which accounted for an additional $11 \%$ of the variance in the biomass data.

Permutation tests identified sewage-derived $\mathrm{N}$ ( $\mathrm{p}=$ 0.043) as the only significant determinant of total macrobenthic biomass change (Table 2). The restricted RDA showed that sewage-derived $\mathrm{N}$ explained $24 \%$ of the biomass variance.

\section{Basin-specific environmental relationships}

Inner reaches

In the inner reaches of Himmerfjärden (Stn 6), interannual change in macrofaunal abundance correlated best with $\mathrm{N}$ discharge from the STP. Using PCA, 78\% of the variance in benthic abundance was explained by the 1st 2 PCA axes. Monte Carlo tests with forward selection indicated $\mathrm{N}$ from the sewage treatment plant ( $p=0.012)$ and hypoxia $(p=0.012)$ as the most significant factors structuring benthic communities in the inner reaches (Table 2). Permutation tests also indicated TN from the adjacent Baltic coastal zone ( $p=0.041)$ as an important determinant of macrobenthic assemblages. Analysis with significant variables showed that the primary RDA axis explained $50 \%$ of the species variance, $92 \%$ of which was related mainly to treated sewage $\mathrm{N}$ inputs (Fig. 6a). The 2nd axis was strongly correlated to hypoxia, but explained only an additional $4 \%$ of community variance. TN in the adjacent Baltic was a negligible $(<1 \%)$ factor regulating the inner reaches species abundance. The species apparently most negatively affected by high influx of sewage N was Macoma balthica, which had its lowest density during the mid-1980s (Fig. 3). Monoporeia affinis also appeared negatively affected by N-loading, while the abundances of Halicryptus spinulosus, Harmothoe sarsi and Pontoporeia femorata were more closely related to duration of hypoxia (H. sarsi) or conditions in the Baltic coastal reference area.

\section{Central reaches}

PCA of the abundance data from the central reaches (Stn 16) explained 68 and $22 \%$ of variance in commu-

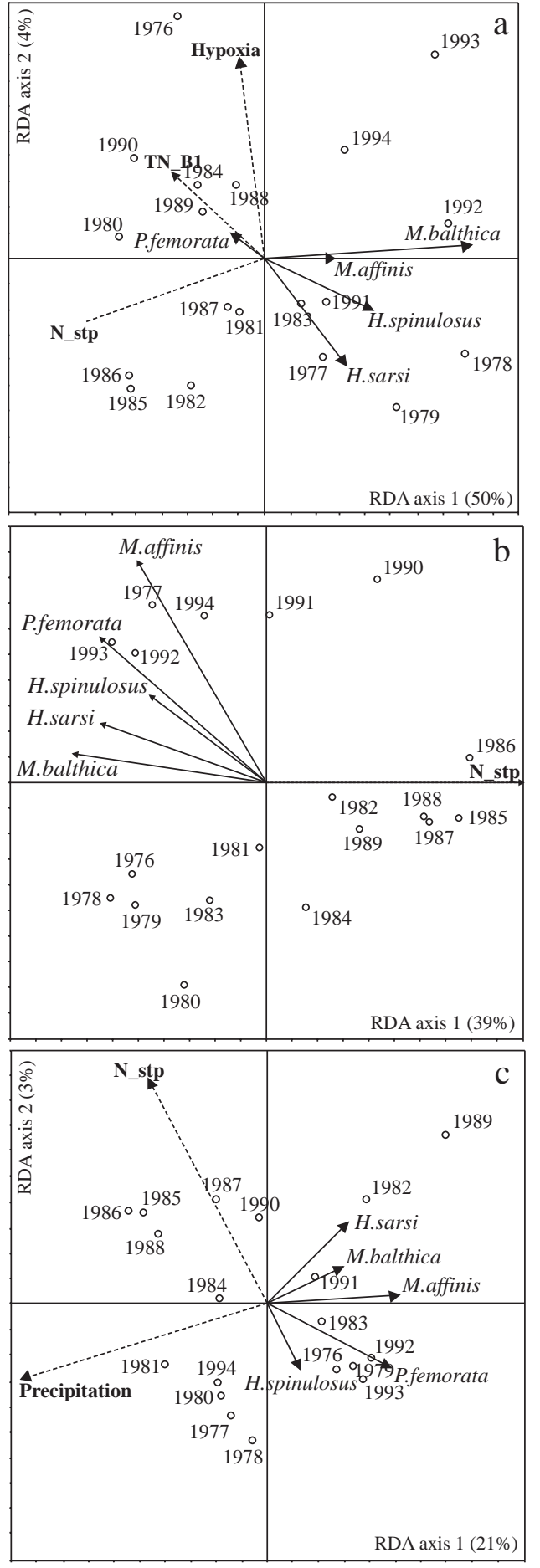

Fig. 6. Redundancy analyses (RDA) of macrobenthic data from the different basins in Himmerfjärden bay ordinated along significant $(\mathrm{p}<0.05)$ environmental gradients. RDA of (a) inner reaches, (b) central reaches and (c) outer reaches abundance data. Environmental gradients include: $\mathrm{N}$ discharge from the sewage treatment plant (N_stp), TN at the B1 coastal reference station (TN_B1), annual total precipitation (precipitation) and the period of hypoxia (hypoxia) (see Table 1) 
nity composition along the 1 st and 2 nd axes, respectively. As for the inner area, forward selection indicated $\mathrm{N}$ from the sewage treatment plant $(\mathrm{p}=0.001)$ as the most highly significant determinant of macrofaunal abundance in the central reaches (Table 2). The restricted RDA showed that sewage $\mathrm{N}$ inputs accounted for $39 \%$ of the explained variance in abundance (Fig. 6b). Abundance was negatively correlated with sewage $\mathrm{N}$-loading for most macrobenthic species, except the amphipods Monoporeia affinis and Pontoporeia femorata which exhibited no clear relationship to $\mathrm{N}$-loading.

\section{Outer reaches}

In the outer reaches (Stn 20), macrofaunal abundance was most strongly correlated with changes in annual rainfall $(\mathrm{p}=0.025)$ and $\mathrm{N}$ discharge from the STP ( $p=0.031)$ was identified as only the 2nd most important factor. The PCA of macrobenthic abundance in the outer reaches explained $66 \%$ of species variance along the 1 st axis and an additional $13 \%$ along the 2 nd axis. Overall, the 1st restricted RDA axis explained $21 \%$ of the species variance, with precipitation mainly accounting for $87 \%$ of the explained variance, while the 2nd RDA axis explained only $3 \%$ more variance, largely due to sewage N-loading (Fig. 6c). The densities of Macoma balthica, Monoporeia affinis and Harmothoe sarsi were negatively correlated to total precipitation, whereas Halicryptus spinulosus and Ponto-

Table 2. Environmental factors identified by Monte Carlo permutation tests with forward selection as significant $(p<0.05)$ in the Himmerfjärden whole bay and basin-wide analyses

\begin{tabular}{|c|c|}
\hline Location & Significant factors \\
\hline $\begin{array}{l}\text { Whole bay } \\
\text { Abundance }\end{array}$ & $\begin{array}{l}\text { Sewage N discharge }(p=0.009) \\
\text { Precipitation }(p=0.028)\end{array}$ \\
\hline Biomass & Sewage $N$ discharge $(p=0.043)$ \\
\hline $\begin{array}{l}\text { Inner reaches } \\
\text { Abundance }\end{array}$ & $\begin{array}{l}\text { Sewage N discharge }(p=0.012) \\
\text { Hypoxia }(p=0.012) \\
\text { TN_B1 (open Baltic) }(p=0.041)\end{array}$ \\
\hline Biomass & Precipitation $(\mathrm{p}=0.046)$ \\
\hline $\begin{array}{l}\text { Middle reaches } \\
\text { Abundance }\end{array}$ & Sewage $N$ discharge $(p=0.001)$ \\
\hline Biomass & $\begin{array}{l}\text { Sewage } N \text { discharge }(p=0.002) \\
\text { Sewage } P \text { discharge }(p=0.048)\end{array}$ \\
\hline $\begin{array}{l}\text { Outer reaches } \\
\text { Abundance }\end{array}$ & $\begin{array}{l}\text { Precipitation }(p=0.025) \\
\text { Sewage N discharge }(p=0.031)\end{array}$ \\
\hline Biomass & - \\
\hline
\end{tabular}

poreia femorata were more abundant when sewage Nloading was low. In general, less variability in annual macrofaunal abundance was explained in restricted RDA of the outer reaches than for the inner and central reaches.

\section{DISCUSSION}

Today, the Baltic and Black Seas are regarded as the seas that most clearly exhibit the combined effects of eutrophication and hypoxia (Diaz 2001). Enclosed estuarine and coastal embayments are particularly prone to develop hypoxia under increased nutrient loads as they tend to have limited water exchange (Diaz \& Rosenberg 2001). For any particular estuary or basin, there is a threshold nutrient level above which hypoxia is likely to develop (Hearn \& Robson 2001). Therefore, to counter eutrophication in Baltic coastal areas, it is considered necessary to reduce the flux both of $\mathrm{N}$, to reduce primary production, and of $\mathrm{P}$, to prevent blooms of potentially toxic cyanobacteria (Rosenberg et al. 1990, Elmgren 2001). However, few studies have investigated the consequences of nutrient reductions on macrobenthic communities. Here, we use concomitant long-term environmental and biotic data from a coastal embayment receiving treated sewage to evaluate the effects of nutrient inputs and enhanced treatment on the composition and biomass of common macrobenthic species.

\section{Temporal trends in macrobenthos}

Our results are largely consistent with the general model of benthic response to organic enrichment, with enhanced abundance and biomass of common species under moderate loading, followed by reductions when nutrient inputs increase further (Pearson \& Rosenberg 1978, Rosenberg 1985, Niermann et al. 1990, Weston 1990, Beukema 1991, Rees et al. 1992). High numbers of Macoma balthica (Bivalvia) and Monoporeia affinis (Amphipoda) dominated the pre-discharge macrobenthic community (Fig. 3). Even before the STP started operating, macrofaunal biomass of the inner basin was already somewhat elevated (Elmgren \& Larsson 1988) in comparison to other coastal areas in the vicinity (Ankar \& Elmgren 1976). This was likely due to prior discharge of a smaller amount of primary treated sewage farther up the bay before the modern treatment plant was installed. The middle and outer reaches of the bay were more typical of neighbouring coastal areas. Following the start of discharge from the STP, $M$. balthica populations peaked and high 
numbers were maintained until the early 1980s. Thereafter, abundance and biomass of the bivalve declined to much lower levels during maximum N-loads. Similarly, populations of $M$. affinis were high under moderate nutrient loading conditions in the early years of discharge. The abundance and biomass of $M$. balthica were re-established again in the late 1980s as N-removal was introduced in the STP. In contrast, populations of $M$. affinis did not return to pre-discharge levels, despite enhanced N-removal. Similarly, Harmothoe sarsi did not respond to nutrient reductions and seemed to decline from 1989 onwards. The other macrobenthic species included in the analyses, Pontoporeia affinis and Halicryptus spinulosus, were generally low throughout the study period and showed no obvious responses to changing nutrient fluxes in the coastal embayment. These findings are largely consistent with the seminal work by Pearson \& Rosenberg (1978), which developed a general model for macrobenthic response to organic enrichment and showed that individual taxa vary in their response to disturbance. We saw no peak of opportunists, such as polychaetes or oligochaetes, however, which may partly be explained by a shortage of candidates for this role in the low salinity and hence, low species richness of the Baltic proper (Elmgren \& Hill 1997).

Reductions in nutrient loads through reduced sewage discharge (Wilson et al. 1998) and abatement of pollution from fish farms (Kraufvelin et al. 2001) have been documented to lead to the recovery of the macrobenthos. In contrast, MDS ordination of abundance data distinguished between pre-discharge communities, those occurring at moderate nutrient levels as well as those occurring during years of high loading (Fig. 4). In particular, populations of Monoporeia affinis did not recover to densities observed prior to sewage discharge, despite the reduced $\mathrm{N}$ flux. This development must, however, be evaluated in relation to continued change also in locally unaffected reference areas in the region, where Macoma balthica populations have expanded and $M$. affinis populations declined over the course of the study (Cederwall et al. 1998), which may be due to general eutrophication of the Baltic proper (Cederwall 2001). Thus, while community composition had partly recovered by 1994, a few years after $\mathrm{N}$ discharge from the STP was reduced, some difference from the pre-discharge community remained. Work in subtropical areas has shown that initial recolonization of macrobenthos is rapid and stable communities are established within 15 mo ( $\mathrm{Lu} \& \mathrm{Wu} 2000)$. In contrast, recovery of macrobenthic communities in temperate zones can take several years (Moore \& Rodger 1991, Bellan et al. 1999, Karakassis et al. 1999, Lardicci et al. 2001).

\section{Whole bay community analysis}

Redundancy analysis of macrobenthic change for the whole Himmerfjärden suggested that both species abundance and biomass responded to a combination of $\mathrm{N}$ from sewage and climatic variability (Fig. 5). $\mathrm{N}$ from the STP was the first factor added to the whole bay RDA models (Table 2), suggesting that it was the best explanatory variable of benthic change. This is consistent with the conclusion that production in the open Baltic proper is regulated mainly by N (Granéli et al. 1990). However, given that most species were negatively correlated with the various $\mathrm{N}$ sources, our analyses indicate that nutrient inputs above a threshold determined by local topography will reduce rather than raise macrobenthic biomass - a pattern that was substantiated in the basin-wide analysis (see below). Precipitation was also a significant predictor of changes in species abundance, implying that inter-annual variation in weather also structures community composition, possibly through precipitation-driven inputs of nutrients from land and Lake Mälaren that could stimulate benthos, or because high rainfall years reflect wind-induced mixing and hence, years with welloxygenated bottom-waters.

Despite inclusion of the same predictive variables in whole bay RDA of macrobenthic community change, species-environmental relationships sometimes varied between analyses conducted using abundance and biomass data. For example, although the common species Macoma balthica and Monoporeia affinis were consistently and inversely related to $\mathrm{N}$ from treated sewage and precipitation, respectively, interpretation of environmental impacts on Harmothoe sarsi varied according to the type of data analysed. When based on species abundance, RDA indicated that $H$. sarsi was negatively correlated to $\mathrm{N}$ in the coastal Baltic zones (Fig. 5b), whereas changes in biomass were unrelated to any measured variable. Similarly, abundance of Halicryptus spinulosus was negatively related to sewage $\mathrm{N}$, whereas its biomass was unaffected by other measured parameters. These differences may also arise from site-specific responses of taxa to environmental forcing factors, patterns that are obscured at the whole bay level, as discussed below.

\section{Spatial patterns of community change}

At the basin-specific level, N from the STP was the single best determinant of benthic change, particularly when community change was expressed as species abundance (Table 2). Sewage-derived $N$ was most highly correlated to community change in the whole bay, inner and central reaches RDA analyses, and was the 
2nd most important factor identified in the outer region analysis. Although N from the STP was correlated with minimum deep-water oxygen concentration, intensity of hypoxia and inputs of sewage-derived P (Fig. 5a), relationships with these variables are usually not statistically significant when colinearity among environmental variables was removed using Monte Carlo analysis.

The consistency of N from STP as the best predictor of community variability suggests that its impacts on biota are real, probably through stimulation of organic matter production. Elsewhere it has been shown that macrobenthic production is often initially stimulated by the increase in organic matter that follows elevated nutrient levels (Pearson \& Rosenberg 1978, Rosenberg 1985, Niermann et al. 1990, Weston 1990, Beukema 1991, Rees et al. 1992). Consequently, one would expect that spring chl a would be a good predictor of macrobenthic change in Himmerfjärden. Spring chl a was, however, only identified as significant in the biomass analysis of the central reaches (Table 2). It must be assumed that summer and autumn production, and lateral input of other food sources (Rosenberg 2001), for example of benthic macro- and microalgae and inputs of organic matter from land and the STP (Hillebrand et al. 2000), are also fuelling the macrobenthos. Such additional inputs would reduce the effectiveness of spring chl $a$ as a predictor of macrobenthic change. In addition, macrobenthic biomass in Himmerfjärden was inversely related to $\mathrm{N}$-loading, suggesting that oxygen deficiency as a result of increased $\mathrm{N}$ inputs may have caused benthic mortality, as is common when organic inputs increase beyond the initial stimulatory stage (Pearson \& Rosenberg 1978). Unexpectedly, the period of hypoxia acted in an opposite direction to N-loading. This may be partly due to an underestimate in terms of the duration of hypoxia, which we chose to define as the period with $<4 \mathrm{mg} \mathrm{O}_{2} \mathrm{l}^{-1}$ in near-bottom water, and partly due to the ability of the dominant species (Macoma balthica) to withstand hypoxia for relatively sustained periods of time (Modig \& Ólafsson 1998). The duration of hypoxia is also likely to be strongly influenced by bottom topography, in combination with the level of organic matter production. Although we cannot eliminate the possibility that other sewage-derived constituents may also have affected the macrobenthos, for example, toxins and metals (Swartz et al. 1982), the consistency of RDA results suggests that $\mathrm{N}$ inputs are the key factor regulating macrobenthic change.

In general, the ability of species-environmental correlations to explain variability in macrobenthic abundance declined with increasing distance from the STP. For example, RDA of the inner reaches explained $54 \%$ of community variance, analysis of the central reaches explained $34 \%$, whereas the outer-area RDA explained only $24 \%$ of changes in community abundance. In con- trast, there was no directional change in the ability of the PCA to summarise community variance (inner: $78 \%$; central: $90 \%$; outer: $79 \%$ ). Thus, while our ability to summarise overall community change was spatially independent, the ability of the measured environmental variables to explain community change declined from the inner to the outer reaches.

Consistent with the premise that the factors that structure macrobenthic communities change through space, the strength of sewage $\mathrm{N}$ as an explanatory variable declined as a function of distance from the STP. Sewage N was strongly correlated to the 1st RDA axis and explained 50 and $39 \%$ community variance in the inner and middle reaches, respectively. By the outer area, sewage-derived $\mathrm{N}$ was correlated to the 2nd axis, which itself explained only $3 \%$ of community variance. Instead, changes in community abundance at this outer station were more clearly correlated to precipitation, with higher abundance of most taxa recorded in years with low precipitation. While precipitation is unlikely to directly influence the macrobenthos, years of low precipitation may reflect low diffuse nutrient sources that contribute to benthic growth at moderate levels, or it may be masking some excluded or unmeasured factor such as wind-induced mixing that improves bottom-water oxygen conditions. These observations suggest that other factors than those included in the analysis control community abundance in the outer reaches of Himmerfjärden bay.

Overall, impacts of the STP on the macrobenthic community seemed to be most clearly expressed in the central reaches of the bay, despite its physical distance from the outfall. Redundancy analyses showed that all taxa responded similarly to environmental factors in the middle region and further identified nutrients from sewage as the sole significant control of community abundance. Strong impacts of sewage N and P in the central reaches likely reflect the deep nature of Stn 16 (52 $\mathrm{m}$ ) and hence, an increased propensity for this station to develop bottom-water anoxia under elevated nutrient conditions (Diaz \& Rosenberg 2001). In fact, all stations deeper than $35 \mathrm{~m}$ in the inner and central reaches exhibited a total die-off of benthos between 1985 and 1990. Shallow stations in the inner and central reaches also showed a decline in benthic abundance in this period, but these reductions were either less pronounced or of shorter duration. In contrast, the outer stations showed few pronounced changes in macrobenthic abundance during 1985 to 1990, regardless of water depth. This was probably because the oxygen content of deep waters at these stations is more closely related to salinity intrusions and bottom-water exchange with the open Baltic (Laine et al. 1997). Moreover, Engqvist (1997) has shown an increase in water retention time in the inner reaches of Himmer- 
fjärden with increasing distance from the open Baltic. Together, these patterns show that while STP nutrient discharges have pronounced and prolonged impacts on the abundance of coastal macrobenthos, the magnitude of these impacts will also depend on the precise physical characteristics of the receiving water body (e.g. sill depth and water circulation).

Species differed in their sensitivity to environmental controls. For example, abundance of Halicryptus spinulosus is negatively correlated with sewage $\mathrm{N}$ in all basins, while abundance of Macoma balthica was inversely related to $\mathrm{N}$-loading in the inner and middle reaches, but not in the outer area, where precipitation was more important. Similarly, Harmothoe sarsi abundance varied as a function of conditions in the Baltic coastal areas, sewage $\mathrm{N}$ and precipitation in the inner, central and outer reaches, respectively. Together these patterns suggest that use of single indicator species to describe sewage effects is likely to be less reliable than community-based approaches. Similarly, high variability in the response of individual species among different areas suggests that interpretation of human impacts based on whole bay analyses may miss subtle site-specific responses of taxa, especially when the main controls of community change differ between areas.

Comparison of redundancy analyses suggested that species biomass was a less sensitive measure of sewage impacts than were abundance-based estimates of community change. For example, while PCA provided an excellent summary of changes in species biomasses (96 to $98 \%$ variance explained), RDA did not consistently identify STP-related factors as key predictors of variability of species biomass. In the inner reaches, only precipitation was retained as a significant explanatory variable and in the outer reaches, biomass variability was unrelated to measured environmental change. While $\mathrm{N}$ and $\mathrm{P}$ from the STP were important determinants of biomass in the central area, comparison of abundance and biomass using RDA analyses suggests that strong impacts of sewage-derived nutrients at the central station may also reflect the importance of depth at this location. Together these patterns suggest that the identification of human impacts on coastal ecosystems may be more effective if analyses are based on changes in species densities rather than overall community biomass. A reason for this may be that biomass changes less rapidly with environmental conditions due to slow growth of Baltic benthos and also because large individuals are more tolerant of oxygen deficiency. Since our comparisons were based on environmental data for each year and macrobenthos data for late in the same year, there simply may not have been enough time for a clear response in biomass.
In summary, analyses of a 23 yr time series of macrobenthic abundance and biomass showed that while moderate sewage loading initially stimulated benthic production, large $\mathrm{N}$ inputs reduced abundance for over a decade, and as far away as over $20 \mathrm{~km}$ from the outfall. Although whole bay multivariate analyses indicated sewage $\mathrm{N}$ as a key determinant of community change, this analysis obscured geographic gradients of species response to disturbance and independent environmental controls, as well as the potentially important interaction between basin morphometry and macrobenthic response to STP discharge. Overall, analyses based on species density appeared more sensitive to nutrient discharge impacts than were biomass-based analyses, and suggested that community recovery was still going on, even $5 \mathrm{yr}$ after introduction of improved $\mathrm{N}$ removal in the STP. Given that inputs of sewage-de-

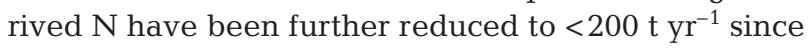
1998, we anticipate that community recovery will continue, particularly in shallow areas that are not prone to bottom-water hypoxia. However, further studies will be needed to quantify both the rate and site-specificity of recovery, and to devise a deterministic model of macrobenthic response to reduced nutrient discharges.

Acknowledgements. Over the years, this study was financially supported by the The Southwestern Stockholm Sewerage Company, the Swedish Environment Protection Agency, Stockholm County Environmental Fund, Himmerfjärdens Naturskyddsförening, Stockholm Vatten AB, The Stockholm Marine Research Centre and the Swedish Foundation for Strategic Environmental Research (MISTRA) through its SUCOZOMA (SUstainable COastal ZOne MAnagement) programme. The $23 \mathrm{yr}$ of macrobenthic and monitoring data were collected, sorted and entered into databases by numerous people at the Askö Laboratory and the Department of Systems Ecology, Stockholm University, with I. Hafdell, A. Sjösten, L. Lundgren and B. Abrahamsson worthy of special mention. P. R. Leavitt and the 4 anonymous reviewers are thanked for valuable and constructive comments on the manuscript.

\section{LITERATURE CITED}

Andersin AB, Lassig J, Parkkonen L, Sandler H (1978) Longterm fluctuations of the soft bottom macrofauna in deep areas of the Gulf of Bothnia 1954-1974; with special reference to Pontoporeia affinis Lindstrom (Amphipoda). Finn Mar Res 244:137-144

Ankar S (1977) Digging profile and penetration of the van Veen grab in different sediment types. Contr Askö Lab Univ Stockholm 16:1-22

Ankar S, Elmgren R (1976) The macro- and meiofauna of the Askö-Landsort area - a stratified random sampling survey. Contrib Askö Lab Univ Stockholm 11:1-115

Bellan G, Bourcier M, Salen-Picard C, Amoux A, Casserley S (1999) Benthic ecosystem changes associated with wastewater treatment at Marseille: implications for the protection and restoration of the Mediterranean coastal shelf ecosystems. Water Environ Res 71:483-493 
Beukema JJ (1991) Changes in the composition of bottom fauna of a tidal-flat area during a period of eutrophication. Mar Biol 111:293-301

Blomqvist S, Larsson U, Borg H (1992) Heavy-metal decrease in the sediments of a Baltic bay following tertiary sewagetreatment. Mar Pollut Bull 24:258-266

Bonsdorff E, Blomqvist EM, Mattila J, Norkko A (1997a) Coastal eutrophication-causes, consequences and perspectives; N. Baltic Sea. Estuar Coast Shelf Sci 44:63-72

Bonsdorff E, Blomqvist EM, Mattila J, Norkko A (1997b) Long-term changes and coastal eutrophication. Examples from the Åland Islands and the Archipelago Sea, northern Baltic Sea. Oceanol Acta 20:319-329

Cao Y, Bark AW, Williams PW (1996) Measuring the responses of macroinvertebrate communities to water pollution: a comparison of multivariate approaches, biotic and diversity indices. Hydrobiologia 341:1-19

Carpenter SR, Caraco NF, Correll DL, Howarth RW, Sharpley AN, Smith VH (1998) Nonpoint pollution of surface waters with phosphorus and nitrogen. Ecol Appl 8:559-568

Cederwall H (2001) Djurlivet på botten-olika styrning på olika nivåer. Östersjö 2000:64-66 (in Swedish)

Cederwall H, Elmgren R (1980) Biomass increase of benthic macrofauna demonstrates eutrophication of the Baltic Sea. Ophelia 1(Suppl):287-304

Cederwall H, Elmgren R (1990) Biological effects of eutrophication in the Baltic Sea, particularly in the coastal zone. Ambio 19:109-112

Cederwall H, Håkansson E, Andersson L (1998) Bottenvatten och mjukbotten fauna. Östersjö 1997:36-40 (in Swedish)

Clarke KR (1993) Non-parametric multivariate analyses of changes in community structure. Aust J Ecol 18:117-143

Diaz RJ (2001) Overview of hypoxia around the world. J Environ Qual 30:275-281

Diaz RJ, Rosenberg R (1995) Marine benthic hypoxia: a review of its ecological effects and the behavioural responses of benthic macrofauna. Oceanogr Mar Biol Annu Rev 33:245-303

Diaz RJ, Rosenberg R (2001) Overview of anthropogenicallyinduced hypoxic effects on marine benthic fauna. In: Rabalais NC, Turner ER (eds) Coastal hypoxia: consequences for living resources and ecosystems. Coastal and Estuarine Studies 58. American Geophysical Union, Washington, DC, p 129-146

Elmgren R (1989) Man's impact on the ecosystem of the Baltic Sea: energy flows today and at the turn of the century. Ambio 18:326-332

Elmgren R (2001) Understanding human impact on the Baltic ecosystem: changing views in recent decades. Ambio 30: 222-231

Elmgren R, Hill C (1997) Ecosystem function at low biodiversity - the Baltic example. In: Ormond RFG, Gage JD, Angel MV (eds) Marine biodiversity: patterns and processes. Cambridge University Press, New York, p 319-336

Elmgren R, Larsson U (1988) Himmerfjärsområdet. Naturvårdsverket rapport 3537. Naturvårdsverket Förlag, Stockholm, p 11-17

Elmgren R, Larsson U (1997) Himmerfjärden: förändringar i ett näringsbelastat kustekosystem i Östersjön. Naturvårdsverket rapport 4565. Naturvårdsverket Förlag, Stockholm, p 197 (in Swedish with English summary)

Elmgren R, Larsson U (2001) Eutrophication in the Baltic Sea area: integrated coastal management issues. In: Von Bodungen B, Turner RK (eds) Science and integrated coastal management. Dahlem University Press, Berlin, p 15-35

Elmgren R, Hansson S, Larsson U, Sundelin B, Boehm PD (1983) The Thesis oil spill: acute and long-term impact on the benthos. Mar Biol 73:51-65
Engle VD, Summers KJ, Gaston GR (1994) A benthic index of environmental condition of Gulf of Mexico estuaries. Estuaries 17:372-384

Engqvist A (1996) Long-term nutrient balances in the eutrophication of the Himmerfjärden estuary. Estuar Coast Shelf Sci 42:483-507

Engqvist A (1997) Vatten - och närsaltutbyte i hela Himmerfjärden. In: Elmgren R, Larsson U (eds) Himmerfjärden: förändringar i ett näringsbelastat kustekosystem i Östersjön. Naturvårdsverket rapport 4565. Naturvårdsverket Förlag, Stockholm, p 120-143 (in Swedish)

Ferraro SP, Swartz RC, Cole FA, Schults DW (1991) Temporal changes in the benthos along a pollution gradient: discriminating the effects of natural phenomena from sewageindustrial wastewater effects. Estuar Coast Shelf Sci 33: 383-407

Field JG, Clarke KR, Warwick RM (1982) A practical strategy for analysing multispecies distribution patterns. Mar Ecol Prog Ser 8:37-52

González-Oreja JA, Saiz-Salinas JI (1998) Exploring the relationships between abiotic variables and benthic community structure in a polluted estuarine system. Water Res 32 : 3799-3807

Granéli E, Wallström K, Larsson U, Granéli W, Elmgren R (1990) Nutrient limitation of primary production in the Baltic Sea area. Ambio 19:142-151

Gray JS, Clarke KR, Warwick RM, Hobbs G (1990) Detection on initial effects of pollution on marine benthos: an example from the Ekofisk and Eldfisk oilfields, North Sea. Mar Ecol Prog Ser 66:285-299

Hearn CJ, Robson BJ (2001) Inter-annual variability of bottom hypoxia in shallow Mediterranean estuaries. Estuar Coast Shelf Sci 52:643-657

Hillebrand H, Worm B, Lotze HK (2000) Marine microbenthic community structure regulated by nitrogen loading and grazing pressure. Mar Ecol Prog Ser 204:27-38

Howarth RW (1998) An assessment of human influences on fluxes of nitrogen from the terrestrial landscape to the estuaries and continental shelves of the North Atlantic Ocean. Nutr Cycl Agroecosyst 52:213-223

Hurrell JW (1995) Decadal trends in the North Atlantic Oscillation: regional temperatures and precipitation. Science 269:676-679

Jongman RHG, Ter Braak CJF, Van Tongeren OFR (1995) Data analysis in community and landscape ecology. Cambridge University Press, Cambridge

Karakassis I, Hatziyanni E, Tsapakis M, Plaiti W (1999) Benthic recovery following cessation of fish farming: a series of successes and catastrophes. Mar Ecol Prog Ser 184:205-218

Kraufvelin P, Sinisalo B, Leppäkoski E, Mattila J, Bonsdorff E (2001) Changes in zoobenthic community structure after pollution abatement from fish farms in the Archipelago Sea (N. Baltic Sea). Mar Environ Res 51:229-245

Laine AO, Sandler H, Andersin AB, Stigzelius J (1997) Longterm changes of macrozoobenthos in the eastern Gotland Basin and the Gulf of Finland (Baltic Sea) in relation to the hydrographical regime. J Sea Res 38:135-159

Lardicci C, Como S, Corti S, Rossi F (2001) Recovery of the macrozoobenthic community after severe dystrophic crises in a Mediterranean coastal lagoon (Orbetello, Italy). Mar Pollut Bull 42:202-214

Larsson U, Elmgren R, Wulff F (1985) Eutrophication and the Baltic Sea-causes and consequences. Ambio 14:9-14

Lindegarth M, Hoskin M (2001) Patterns of distribution of macro-fauna in different types of estuarine, soft sediment habitats adjacent to urban and non-urban areas. Estuar Coast Shelf Sci 52:237-247 
Lu L, Wu RSS (2000) An experimental study on recolonization and succession of marine macrobenthos in defaunated sediment. Mar Biol 136:291-302

Modig H, Ólafsson E (1998) Responses of Baltic benthic invertebrates to hypoxic events. J Exp Mar Biol Ecol 229: 133-148

Moore DC, Rodger GK (1991) Recovery of a sewage sludge dumping ground. II. Macrobenthic community. Mar Ecol Prog Ser 75:301-308

Niermann U, Bauerfeind E, Hickel W, Westernhagen HV (1990) The recovery of benthos following the impact of low oxygen content in the German bight. Neth J Sea Res 25: 215-311

Pearson TH, Rosenberg R (1978) Macrobenthic succession in relation to organic enrichment and pollution of the marine environment. Oceanogr Mar Biol Annu Rev 16: 229-311

Powilleit M, Kube J (1999) Effects of severe oxygen depletion on macrobenthos in the Pomeranian Bay (southern Baltic Sea): a case study in a shallow, sublittoral habitat characterised by low species richness. J Sea Res 42:221-234

Rakocinski CF, Brown SS, Gaston GR, Heard RW, Walker WW, Summers KJ (1997) Macrobenthic responses to natural and contaminant-related gradients in northern Gulf of Mexico estuaries. Ecol Appl 7:1278-1298

Rees HL, Eleftheriou A (1989) North Sea benthos: a review of field investigations into biological effects of man's activities. J Cons Int Explor Mer 45:284-305

Rees HL, Rowlatt SM, Lambert MA, Lees RG, Limpenny DS

Editorial responsibility: Otto Kinne (Editor),

Oldendorf/Luhe, Germany
(1992) Spatial and temporal trends in the benthos and sediments in relation to sewage sludge disposal off the northeast coast of England. ICES J Mar Sci 49:55-64

Rosenberg R (1985) Eutrophication - the future marine coastal nuisance? Mar Pollut Bull 16:227-331

Rosenberg R (2001) Marine benthic faunal successional stages and related sedimentary activity. Sci Mar 65:107-119

Rosenberg R, Elmgren R, Fleischer S, Jonsson P, Persson G, Dahlin H (1990) Marine eutrophication case studies in Sweden. Ambio 19:102-108

Swartz RC, Deben WA, Sercu KA, Lamberson JO (1982) Sediment toxicity and the distribution of amphipods in Commencement Bay, Washington, USA. Mar Pollut Bull 13:359-364

Ter Braak CJF (1990) CANOCO: a FORTRAN program for canonical community ordination. Microcomputer Power, Ithaca, NY

Warwick RM (1993) Environmental impact studies on marine communities: pragmatical considerations. Aust J Ecol 18: $63-80$

Warwick RM, Clarke KR (1991) A comparison of some methods for analysing changes in benthic community structure. J Mar Biol Assoc UK 71:225-244

Weston DP (1990) Quantitative examination of macrobenthic community changes along an organic enrichment gradient. Mar Ecol Prog Ser 61:233-244

Wilson RS, Heislers S, Poore GCB (1998) Changes in benthic communities of Port Phillip Bay, Australia, between 1969 and 1995. Mar Freshw Res 49:847-861

Submitted: April 10, 2002; Accepted: July 23, 2002

Proofs received from author(s): October 22, 2002 